\title{
Particle size distributions in the Eastern Mediterranean troposphere
}

\author{
N. Kalivitis ${ }^{1}$, W. Birmili ${ }^{2}$, M. Stock ${ }^{2, *}$, B. Wehner ${ }^{2}$, A. Massling ${ }^{2, * *}$, A. Wiedensohler ${ }^{2}$, E. Gerasopoulos ${ }^{1, * * *}$, and \\ N. Mihalopoulos ${ }^{1}$ \\ ${ }^{1}$ Environmental Chemical Processes Laboratory, Department of Chemistry, University of Crete, Greece \\ ${ }^{2}$ Leibniz-Institute for Tropospheric Research, Leipzig, Germany \\ *now at: Alfred Wegener Institute for Polar and Marine Research, Potsdam, Germany \\ ** ${ }^{*}$ now at: National Environmental Research Institute, Aarhus University, Roskilde, Denmark \\ **** now at: Institute for Environmental Research and Sustainable Development, National Observatory of Athens, \\ Athens, Greece
}

Received: 26 February 2008 - Published in Atmos. Chem. Phys. Discuss.: 4 April 2008

Revised: 19 September 2008 - Accepted: 22 September 2008 - Published: 24 November 2008

\begin{abstract}
Atmospheric particle size distributions were measured on Crete island, Greece in the Eastern Mediterranean during an intensive field campaign between 28 August and 20 October, 2005. Our instrumentation combined a differential mobility particle sizer (DMPS) and an aerodynamic particle sizer (APS) and measured number size distributions in the size range $0.018 \mu \mathrm{m}-10 \mu \mathrm{m}$. Four time periods with distinct aerosol characteristics were discriminated, two corresponding to marine and polluted air masses, respectively. In marine air, the sub- $\mu \mathrm{m}$ size distributions showed two particle modes centered at $67 \mathrm{~nm}$ and $195 \mathrm{~nm}$ having total number concentrations between 900 and $2000 \mathrm{~cm}^{-3}$. In polluted air masses, the size distributions were mainly unimodal with a mode typically centered at $140 \mathrm{~nm}$, with number concentrations varying between 1800 and $2900 \mathrm{~cm}^{-3}$. Super- $\mu \mathrm{m}$ particles showed number concentrations in the range from 0.01 to $2.5 \mathrm{~cm}^{-3}$ without any clear relation to air mass origin. A small number of short-lived particle nucleation events were recorded, where the calculated particle formation rates ranged between $1.1-1.7 \mathrm{~cm}^{-3} \mathrm{~s}^{-1}$. However, no particle nucleation and growth events comparable to those typical for the continental boundary layer were observed. Particles concentrations (Diameter $<50 \mathrm{~nm}$ ) were low compared to continental boundary layer conditions with an average concentration of $300 \mathrm{~cm}^{-3}$. The production of sulfuric acid and its subsequently condensation on preexisting particles was ex-
\end{abstract}

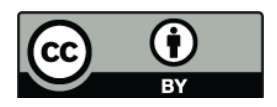

Correspondence to: N. Mihalopoulos (mihalo@chemistry.uoc.gr) amined with the use of a simplistic box model. These calculations suggested that the day-time evolution of the Aitken particle population was governed mainly by coagulation and that particle formation was absent during most days.

\section{Introduction}

During the past decades, atmospheric research has been concerned with the global distribution of atmospheric aerosol particles because of their effects on global climate by interaction with the incoming solar radiation (Haywood and Boucher, 2000; Lohmann and Feichter, 2005), their oxidation capacity of the atmosphere (Ravishankara, 1997), and their adverse effects on human health (HEI, 2002; WHO, 2004). Aerosols are identified to play a key role on earth radiation budget alleviating Green House Gases (GHGs) effects, it is therefore vital to understand the past and possible future influence of aerosols on regional and global climate (Solomon et al., 2007).

The Mediterranean area is of special interest for global climate research because its atmosphere is influenced likewise by continental and maritime aerosol sources and complex boundary layer processes. Especially for the Eastern Mediterranean area, the dominance of northerly winds during summer leads to transport of polluted air masses from the main continental Europe (e.g. Lelieveld et al., 2002). Moreover, due to its proximity to North Africa, Saharan dust can be frequently observed during the transition periods (e.g. Kalivitis et al., 2007). The combination of solar

Published by Copernicus Publications on behalf of the European Geosciences Union. 
irradiance with the sea water in the marine environment results in high levels of relative humidity $(\mathrm{RH})$, that causes aerosols to take up water and therefore contribute significantly to direct radiative forcing even in the absence of clouds. Indeed, during July/August 2001, Markowicz et al. (2002) showed that aerosols of anthropogenic origin in the Eastern Mediterranean area, can contribute to a diurnal average reduction of $17.9 \mathrm{~W} \mathrm{~m}^{-2}$ in the surface solar radiation, an increase of $11.3 \mathrm{~W} \mathrm{~m}^{-2}$ in the atmospheric solar absorption, and an increase of $6.6 \mathrm{~W} \mathrm{~m}^{-2}$ in the reflected solar radiation at the top-of-the atmosphere. Moreover, Vrekoussis et al. (2005) deduced radiative forcing estimates at the top of the atmosphere (TOA) in the order of $-10 \mathrm{~W} \mathrm{~m}^{-2}$ during the dry period (May to October).

Atmospheric particle number size distributions are among the most important parameters from which the atmospheric effects of an aerosol population can be derived (Penner et al., 1998). Since particle number size distributions can be measured with high time resolution, they can be used to distinguish between different air mass types, as well as to identify particle formation, and possibly transformation and removal processes. In situ observations of particle number size distributions in the Eastern Mediterranean are thus important for evaluation of these processes, however they are scarce, and have been limited to restricted periods in urban areas (e.g. Petäjä et al., 2007).

To better understand the variability and climatic role of aerosols in Eastern Mediterranean, intensive measurements of atmospheric aerosol particles were conducted between August and October 2005 at a remote location on Crete Island (ARIADNE - Aerosol Physical and Chemical Identification on Crete). The main goals of the ARIADNE field study were to determine representative atmospheric particle number size distributions and analyze them according to their potential source regions. Additional results from the campaign, such as the hygroscopic particle properties and chemical particle composition will be presented in a separate paper.

\section{Experimental}

\subsection{The atmospheric research station at Finokalia, Crete}

Particle measurements were conducted between 29 August and 20 October, 2005 at the Finokalia research station, a remote coastal site in the northeastern part of the island of Crete, Greece $\left(35^{\circ} 20^{\prime} \mathrm{N}, 25^{\circ} 40^{\prime} \mathrm{E}\right)$. Heraklion, the largest city on Crete with a population of about 140.000 inhabitants can be found $70 \mathrm{~km}$ east of Finokalia. A major urban agglomeration on the northern shore of the Mediterranean is Athens ( $\sim .5$ Mio. inhabitants), located about $350 \mathrm{~km}$ northwest of the station. Athens and other urban centers of continental Europe and Asia are the main sources of pollution transported over eastern Mediterranean, mainly in summer when N-NW winds prevail (Gerasopoulos et al., 2005). A detailed description of the measurement site and the prevailing meteorology has been given by Mihalopoulos et al. (1997). Further details on the current operations at Finokalia can be found on http://finokalia.chemistry.uoc.gr.

\subsection{Measurements and methods}

Ambient particle number size distributions were measured using a flow-controlled differential mobility particle sizer (DMPS). This instrument follows the general design described in Birmili et al. (1999). Briefly, the instrument consisted of a differential mobility analyzer (DMA; Vienna type, cf. Winklmayr et al., 1991), combined with a condensation particle counter (model 3010, TSI Inc., St. Paul). The system scanned across a particle size range between 18 and $800 \mathrm{~nm}$. Sheath air was circulated in a closed loop and maintained at relative humidities between 10 and 30\%. The aerosol inlet was equipped with an Andersen $\mathrm{PM}_{10}$ sampling head. Because of the high absolute humidity present in ambient air, aerosol samples were dried before mobility analysis in a diffusion drier based on the Nafion ${ }^{\mathrm{TM}}$ membrane technology (Perma Pure LLC Inc., Toms River, USA). This drying step was crucial because the laboratory container at Finokalia was air-conditioned with temperature control at $22^{\circ} \mathrm{C}$, so that in the case of significantly higher ambient temperatures to avoid water condensation in the aerosol lines entering the container. Based on laboratory calibrations, the effect of particle losses during the passage of aerosol through the diffusion drier can be neglected for the size range $18-800 \mathrm{~nm}$ where the DMPS system was operated.

In addition to the DMPS, coarse particle number size distributions were measured across an aerodynamic particle size range between 0.8 and $10 \mu \mathrm{m}$ using an aerodynamic particle sizer (APS; model 3321, TSI Inc., St. Paul, USA; see Peters and Leith, 2003). To obtain complete particle number size distributions in the range $18 \mathrm{~nm}-10 \mu \mathrm{m}$ we have transformed the APS distributions from aerodynamic to electromobility diameter.

During ARIADNE concurrent measurements were carried out in order to fully characterize the physico-chemical properties of atmospheric particles in the area of Eastern Mediterranean. $\mathrm{PM}_{10}$ particulate matter was monitored using an Eberline FH 62 I-R Particulate monitor and ozone concentration was measured continuously by a Thermo Electron 49C. Finally, regular sampling of TSP using filters and $\mathrm{PM}_{10}$ Small Deposit area low pressure Impactor sampling (SDI; Maenhaut et al., 1996) was provided to determine the chemical composition of the observed atmospheric particles.

The identification of the wind direction and air mass origin was based on 5-day back-trajectories calculated by the HYSPLIT model (Hybrid Single-Particle Lagrangian Integrated Trajectory Model; Draxler and Hess, 1998). 

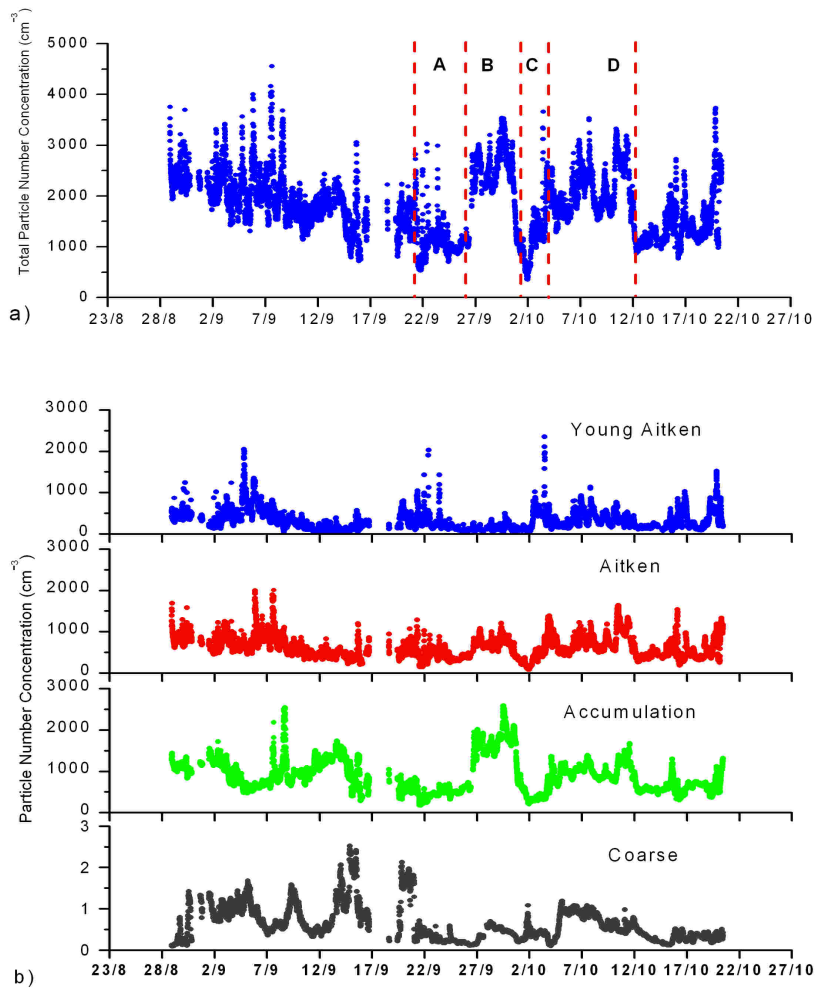

Fig. 1. Particle concentrations at Finokalia, Crete between 28 August and 20 October, 2005: (a) total number ( $>18 \mathrm{~nm})$, (b) Young Aitken $(18-50 \mathrm{~nm})$, Aitken $(50-100 \mathrm{~nm})$, accumulation $(100-1000 \mathrm{~nm})$ and coarse $(1-10 \mu \mathrm{m})$ particle concentrations. Periods $\mathrm{A}, \mathrm{B}, \mathrm{C}$ and $\mathrm{D}$ are defined in Table 1 .

\section{Observations}

\subsection{Particle number concentrations}

The total particle number concentration at Finokalia station for the period 28 August-20 October 2005 is shown in Fig. 1a. Three frequency ranges of variability were evident: the low-frequency variability demonstrating the reduction of particle number from late summer to autumn, the midfrequency variability in the order of few days, possibly corresponding to different synoptic conditions and air mass origins, and finally the high-frequency variability represented as short-duration, episodical spikes.

The influence from air masses with different characteristics is examined with back trajectory analysis using the HYSPLIT model. Throughout the whole period air masses from the wide NW-NE sector prevailed (83\% of the period), indicating influence from continental Europe sources. During the rest of the days air masses originated either from $\mathrm{W}$ or SW. The average total particle number concentration was about $1800 \mathrm{~cm}^{-3}$, the maximum was $4560 \mathrm{~cm}^{-3}$ and the minimum was $360 \mathrm{~cm}^{-3}$, the latter being typical for remote coastal ar-

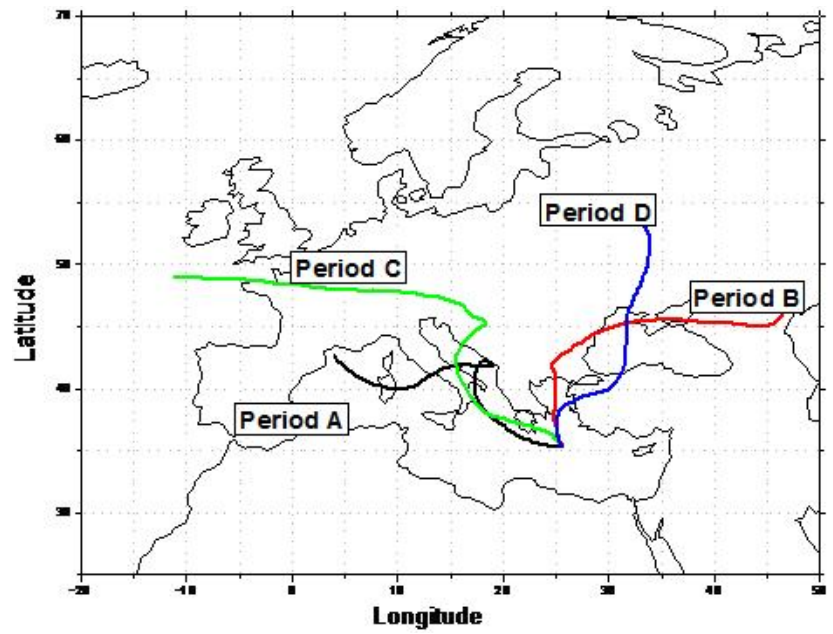

Fig. 2. Representative back trajectories illustrating maritime air masses corresponding to Period $\mathrm{A}$ and $\mathrm{C}$ and polluted air masses corresponding to Period B and D.

eas (Seinfeld and Pandis, 1998). During the first period of the field study (28 August- 8 September) air masses from industrialized areas over Turkey, Eastern and Western Europe resulted to high aerosol loading over Finokalia station. On 9 September, particle number concentrations started gradually decreasing and henceforth lower levels of concentrations were established with observed elevations mainly due to certain episodes.

During this study, four periods were distinguished by different levels of total particle number concentration, which also corresponded to different air mass origins as shown in Fig. 2: Period A (21-25 September) represents air masses originating over Western Mediterranean, with particle number concentrations ranging between $900-1200 \mathrm{~cm}^{-3}$ (interquartile range), and thus this period corresponds to maritime aerosols. During period B (27-30 September) northerlies prevailed, introducing pollution aerosols from continental Greece and Eastern Europe, resulting in elevated particle loadings (2300-2900 $\left.\mathrm{cm}^{-3}\right)$. During period C (1-4 October) maritime aerosols enriched with pollution from Western $\mathrm{Eu}-$ rope, leaded to intermediate concentrations in the range of $1200-2000 \mathrm{~cm}^{-3}$. Finally, period D (5-12 October) was influenced by continental air masses arriving from Turkey and the Black Sea, resulting in total particle number concentrations of $1800-2500 \mathrm{~cm}^{-3}$. The above defined periods will be used for identifying average distributions accounting for different types of air masses. Representative particle number concentration values for each period are summarized in Table 1.

To understand the variability of total particle number concentrations, particle number time series for different size ranges are plotted in Fig. 1b. We have discriminated between the following size ranges: Young Aitken $(18-50 \mathrm{~nm})$, Aitken 


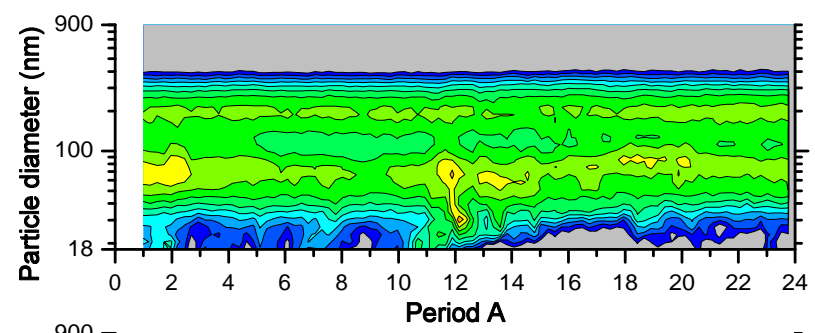

Table 1. Classification of four distinct air masses and their corresponding total particle number concentration (Diameter $>18 \mathrm{~nm}$ ).

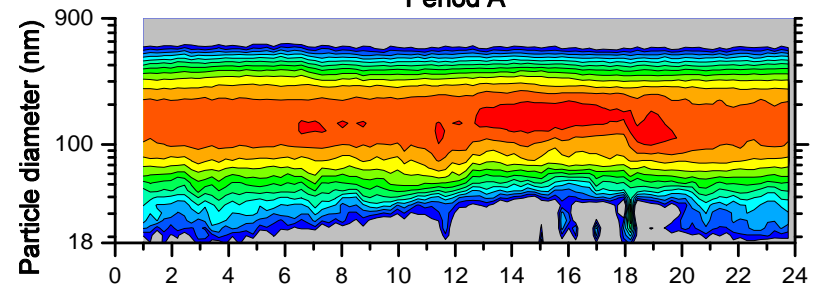

Period B
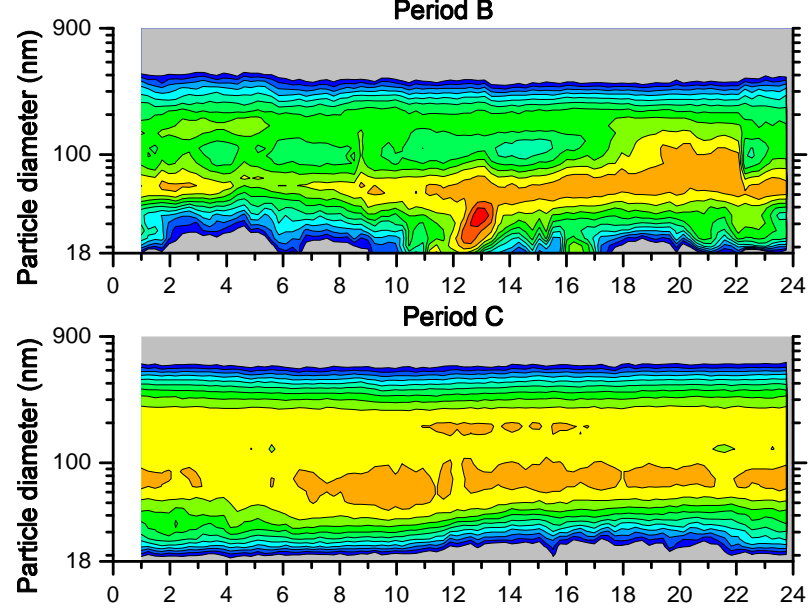

Period D

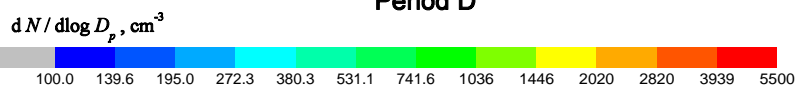

mation as can be seen in the Young Aitken mode (Fig. 1b). These spikes are evident when very low number concentrations of accumulation mode particles are observed, especially when maritime air masses prevailed, such as periods A and C of Fig. 1a. Since accumulation particles are limited in number, precursor gases are not scavenged onto preexisting particles and formation of new particles is possible as discussed in Sect. 3.3.

\subsection{Particle size distributions}

\subsubsection{Air-mass specific size distributions}

Apart from the particle number concentrations, number size distributions were additionally examined. The mean diurnal evolution of the number size distributions for each of the distinguished periods A, B, C and D of Fig. 1 are presented in Fig. 3. Two typical size distributions were found during the period under study, characteristically for background and

Fig. 3. Average diurnal cycle of the particle number size distributions during the four periods defined in Table 1. Abscissa represents local time.

(50-100 nm), accumulation (100-1000 nm) and coarse (1$10 \mu \mathrm{m})$. On average, half of total particle number was derived from the accumulation mode, one third lied in the Aitken mode and the rest were Young Aitken mode particles. Coarse particles were limited in number, however when reaching their maximum concentration, they can be a significant portion of the total particle volume and particle mass as discussed later. The low frequency variability of the total particle number concentrations was controlled by both Aitken and accumulation modes, indicating the equally significant role of the regional/local sources and transported particles during this period.

The accumulation mode, corresponding to transported pollution aerosols, is mainly responsible for the mid-frequency variability e.g. 11-14 and 27-30 September 2005. Finally, a certain number of spikes were related with new particle forpolluted conditions respectively (Fig. 4). During the prevalence of maritime air masses, considered as background for the remote coastal station of Finokalia, a bimodal size distribution was found (Fig. 4a).

During these cases the Aitken and the accumulation modes were well distinguished, and the aerosol loading in both modes was low to moderate. An additional characteristic of these cases was that the Young Aitken mode included only a small fraction of the total particle number. When local/regional sources or long range transported air masses influenced the area, then pollution particles were superimposed on the background bimodal distribution. The result was a unimodal size distribution (Fig. 4b) in the accumulation mode range with high aerosol loading (notice the different colour scale in the two graphs). A very interesting phenomenon is evidenced in Fig. 4b. Between 12:00 and 20:00 LT particles below $40 \mathrm{~nm}$ vanished and then appeared again. This phenomenon has been observed several times during the two month measurement period and is explicitly investigated in Sect. 4. 

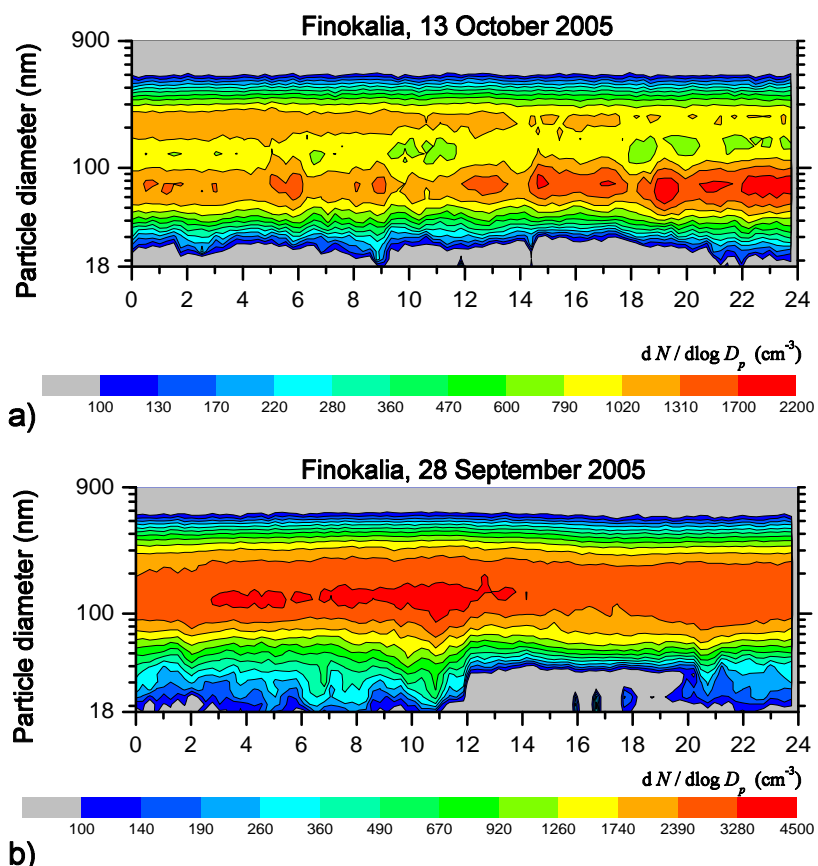

b)

Fig. 4. Extreme cases of particle number size distributions during the influence of (a) maritime air and (b) polluted continental air. Abscissa represents local time.

For a more detailed investigation of typical characteristics of the measured particle number size distributions, average distributions have been calculated for periods A, B, C and D. In Fig. 5 the distributions for periods A, B and C are shown as representative of maritime, polluted and mixed conditions while the distribution for period $\mathrm{D}$ is identical to period $\mathrm{C}$ but with lower loading. Log-normal distributions have then been fitted and average geometric median diameters and standard deviations were extracted. In the case of maritime/background air masses (period A) the Aitken and the accumulation mode peak diameters were found at 66 and $195 \mathrm{~nm}$, respectively, while during period $\mathrm{C}$ the influence from anthropogenic sources was seen as an enhancement of the Aitken mode towards peak diameters of somewhat finer particles $(53 \mathrm{~nm})$. During period B (polluted air masses) the average typically observed unimodal size distribution was centered around $139 \mathrm{~nm}$.

\subsubsection{New particle formation}

The particle number size distributions during the ARIADNE field experiment were screened for possible events of secondary particle formation. The formation of new particles from gaseous precursors represents a major source of particle number (Kulmala et al., 2004), and it was not clear before our observations whether this phenomenon would happen in the East Mediterranean region frequently.

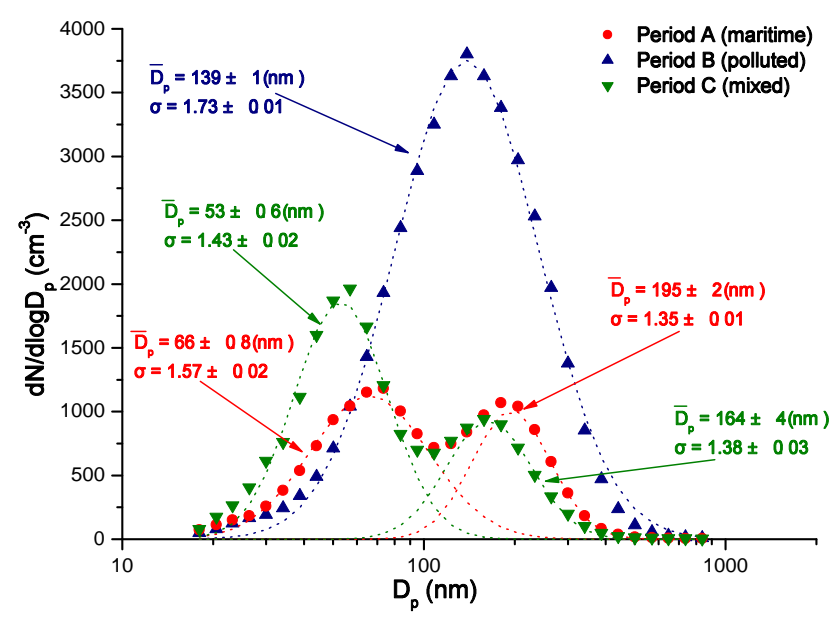

Fig. 5. Particle number size distributions representing different degrees of anthropogenic influence: Air masses A, B and C defined in Table 1.

Owing to the lower size limit of our DMPS system, a particle formation event was defined as a period when high concentrations of particles occurred in the smallest size interval (18-25 nm). Between 29 August and 20 October 2005, only three new particle formation events were observed at Finokalia. These three cases met the criteria given in Birmili et al. (2003) to qualify as a significant particle formation event. The time for the Young Aitken curve to rise from $1 / \mathrm{e}$ of maximum to maximum value was between 0.5 and $1 \mathrm{~h}$, and similar values were found for the declining branch. Maximum number concentrations $<50 \mathrm{~nm}$ ranged between $1400-2400 \mathrm{~cm}^{-3}$, which corresponded to $40-55 \%$ of the total particle number concentration.

Formation rates for particles with diameters larger than $18 \mathrm{~nm}\left(\mathrm{~J}_{18}\right)$ ranged between 1.1 and $1.7 \mathrm{~cm}^{-3} \mathrm{~s}^{-1}$ and were determined by dividing the concentration of new particles formed by the time necessary to reach the concentration maximum (Kulmala et al., 2004; their Eq. 3). This is a good approximation for air masses reaching Finokalia during this period which can be considered relatively clean and homogeneous since the pre-event concentration of particles remained below $1200 \mathrm{~cm}^{-3}$ and back trajectory analysis showed that western winds prevailed. Therefore the effects of both coagulation and transport can be considered small compared with particle production.

Figure 6 presents one of the three particle formation events, starting on 23 September at 11:00 LT. The occurrence of small particles $(<50 \mathrm{~nm})$ is limited to under two hours. This observation suggests that the particle formation took place in a small cell of the atmosphere only. All events observed during our experiment occurred during midday, suggesting that photochemical processes play key role.

It is an important observation that despite the large amounts of solar radiation encountered almost every day in 


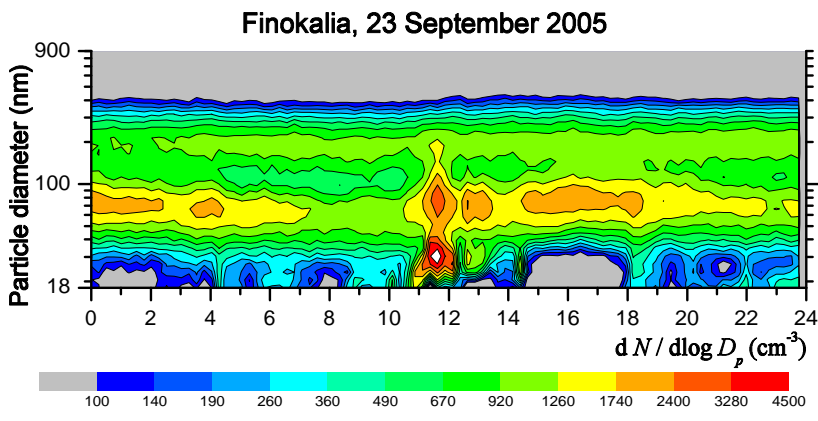

Fig. 6. New particle formation event observed on 23 September 2005 at Finokalia. Abscissa represents local time.

the cloudless atmosphere over Crete, we recorded no largearea nucleation and growth events that are rather typical for the continental boundary layer (e.g., Kulmala et al., 2004; Heintzenberg et al., 2007). It remains a current subject of speculation why this is so. Reasons could be the lack of aerosol precursors, the scavenging of precursors by a large particle surface area in a regime of high relative humidity, or the lack of a vertical atmospheric exchange that is necessary to lift precursors to higher levels where temperatures are low and thus favorable for particle nucleation.

\subsection{Apparent particle density and mass closure considera- tion}

Particle number concentrations measured by electromobility analysis (e.g. SMPS) are based on the electromobility diameter which, after the elimination of multiple charge effects, is the particles' Stokes' diameter. On the other hand other techniques (e.g. gravimetric, APS) provide aerosol measurements based on aerodynamic diameters and thus any comparison with the above requires assumption for particle shape and particle density. Combining SMPS data with mass concentrations, we estimated the range of apparent densities and then discussed how realistic these densities are.

Towards this direction particle volume concentrations were calculated from number concentrations assuming spherical particles. Volume concentrations were calculated separately for the fine and the coarse modes ( $1 \mu \mathrm{m}$ cut off), and are plotted together with the $\mathrm{PM}_{10}$ mass concentration at Finokalia station for the same period (Fig. 7). Here, it is evident that the fine aerosol fraction controlled by far the variability of the total particle mass concentrations. Since the number concentration of coarse particles is very low, inducing significant errors in the coarse particle volumes, we have confined the estimation of apparent densities to the fine fraction of particles $(<1 \mu \mathrm{m})$.

For this we need $\mathrm{PM}_{1}$ dry mass which was calculated assuming that continuous $\mathrm{PM}_{10}$ measurements correspond to dry mass and additionally using the SDI mass size distributions during that period. $\mathrm{PM}_{1} / \mathrm{PM}_{10}$ ratios from im- pactor measurements were accommodated (Gerasopoulos et al., 2007) taking into account the conversion from aerodynamic to physical diameters. For the estimation of the $\mathrm{PM}_{1}$ mass concentration we assumed that the fine mass fraction corresponds to the mass collected on the impactor stages with cutoff diameter smaller than $1.3 \mu \mathrm{m}$ (physical diameter) (Saarikoski et al., 2005). This cutoff diameter is the most representative of the fine particulate mass, leading however to an overestimation of fine particle apparent density.

For the days with impactor samples, a $\mathrm{PM}_{1}$ time series was reconstructed from the continuous $\mathrm{PM}_{10}$ data set shown in Fig. 7, assuming a constant $\mathrm{PM}_{1} / \mathrm{PM}_{10}$ ratio during each 2-3 day sampling period. Within ARIADNE, nine impactor samples were available and the apparent fine particle densities are shown in Fig. 8. In all cases, median densities ranged between $1-1.7 \mathrm{~g} \mathrm{~cm}^{-3}$. Considering that the main part of the fine particle mode consisted of ammonium sulfate (Sciare et al., 2005), which has a density of $\rho=1.75 \mathrm{~g} \mathrm{~cm}^{-3}$ (Lide, 1991), and organic matter assuming here a density of $\rho=1.2 \mathrm{~g} \mathrm{~cm}^{-3}$ (Turpin and Lim, 2001), the calculated values were within a range of realistic densities for fine particles. Although chemical composition measurements are available, a direct comparison is not easy due to the numerous assumptions made in the calculations.

\section{Disappearing Aitken particles: observations and model simulations}

\subsection{Systematic disappearance of Aitken particles}

The systematic disappearance, or depletion of Aitken particles with diameters below $50 \mathrm{~nm}$ was observed at Finokalia station as a reoccurring feature. Example for this behavior are pictured in Figs. 6, 9a and 10a. As can be seen in Fig. 9a, this disappearance of Aitken particles took place gradually over hours, so that it is unlikely that it can be explained by air mass changes that involve rather abrupt changes in concentration. The disappearance was identified at almost half of all days, and its special pattern highly differed case by case.

Two patterns of Young Aitken particles depletion have been observed. The first pattern is characterized by a gradual depletion of the particles. In general, this pattern is not necessarily related to diurnal variation of solar irradiance, as its initiation appeared in the late afternoon or even before sunrise. The second pattern occurred only during day time and the maximum depletion was observed at noon or in the early afternoon while the depletion rate was more rapid. Both the depletion intensity and the frequency of the Aitken mode depletion events, decreased from summer to winter (not shown here), indicating that they were strongly dependent on solar irradiance variation and its impacts. The main mechanism driving this process is suspected to be either condensation of gas phase species onto small particles or coagulation 


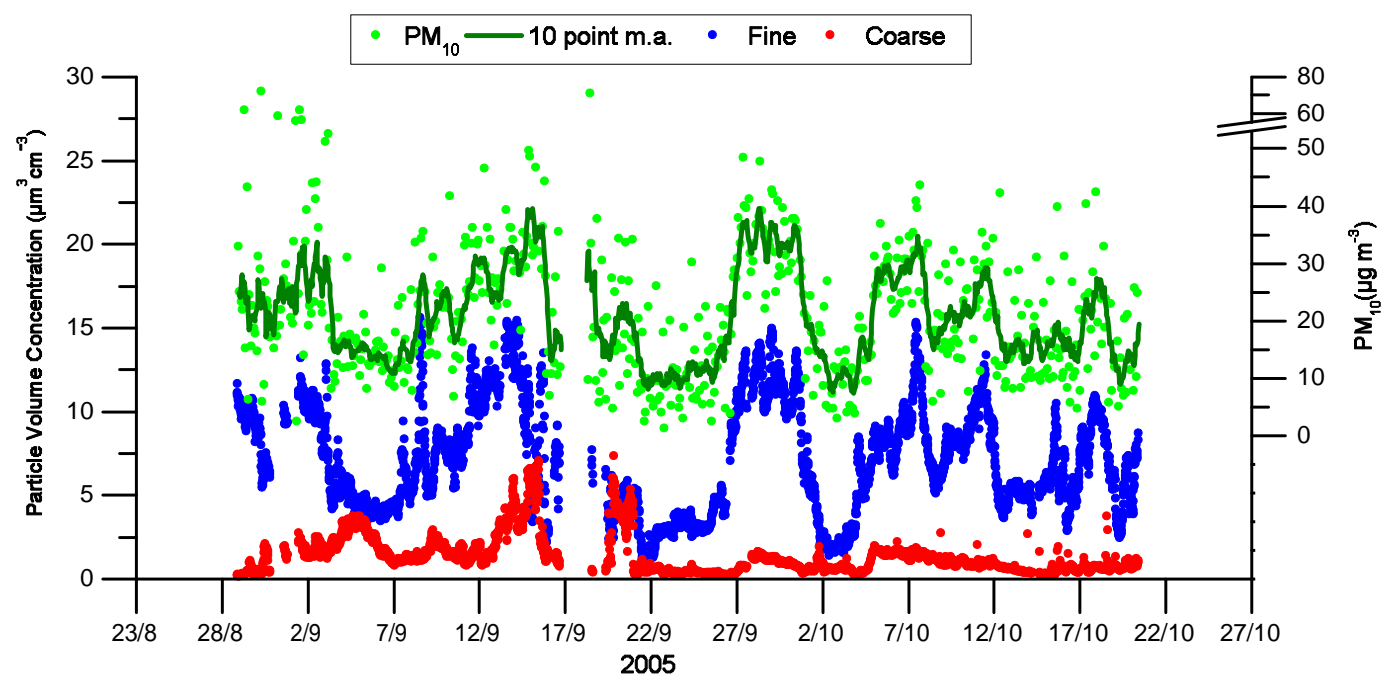

Fig. 7. Fine $(<1 \mu \mathrm{m})$ and coarse $(>1 \mu \mathrm{m})$ particle volume concentrations as well as $\mathrm{PM}_{10}$ mass concentration at Finokalia station.

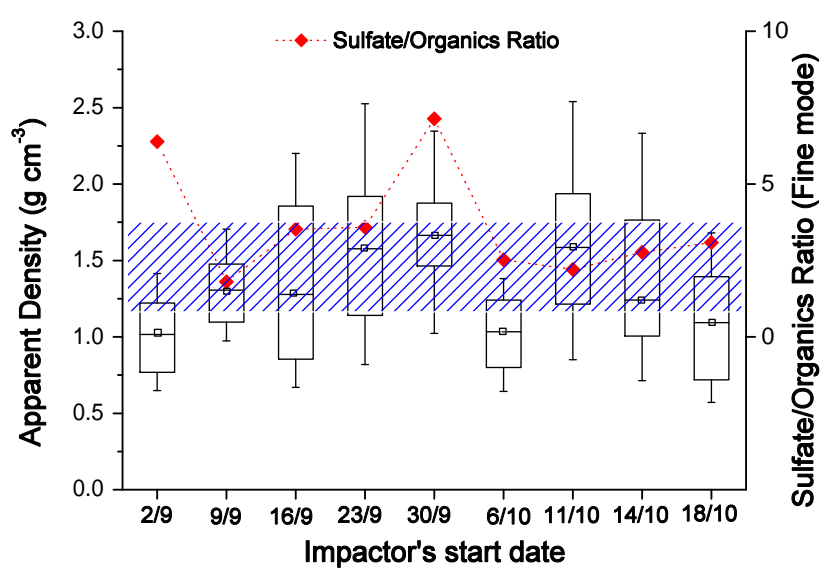

Fig. 8. Apparent fine particle density at Finokalia. Calculations were made assuming a constant $\mathrm{PM}_{1} / \mathrm{PM}_{10}$ ratio during each sampling period.

processes. In order to study the impact of such a process, simulations of $\mathrm{H}_{2} \mathrm{SO}_{4}$ condensation on the measured distributions and coagulation within the existing particle number size distribution were performed.

\subsection{Model description}

A simplistic aerosol dynamics box model was applied to simulate the potential effects of coagulation and condensation on the particle number size distribution. The objective was not to achieve a full microphysical description of aerosol dynamical processes - this would require the implementation of gas phase chemical reactions, mass transfer rates, chemical reactions within the particle as well as heterogeneous chemical
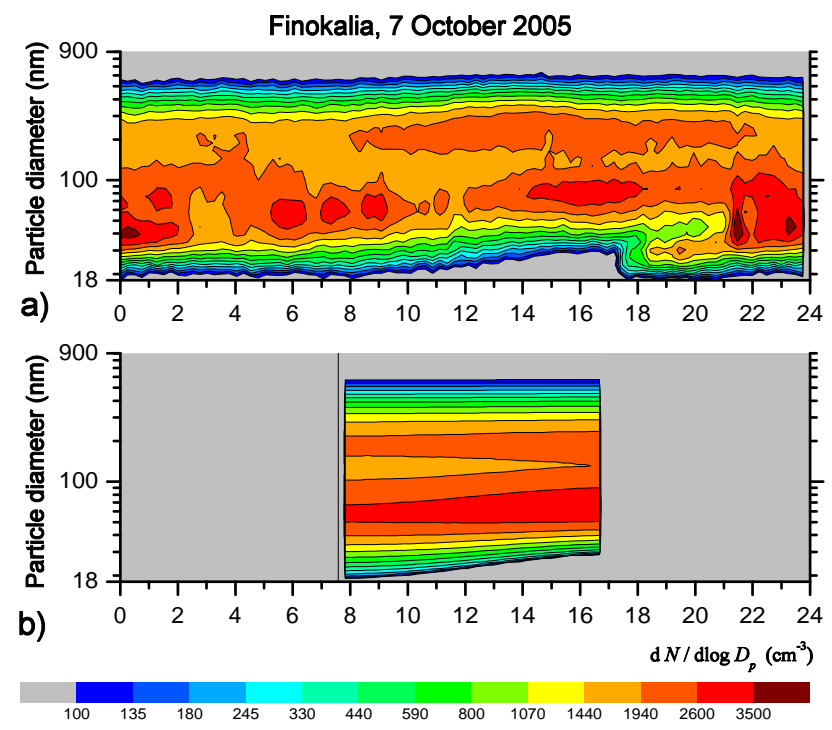

Fig. 9. Particle number size distributions at Finokalia on 7 October 2005: (a) Measurement illustrating the gradual disappearance of Aitken mode particles, (b) box model simulation starting at 08:00 LT and involving only condensation and particle coagulation. Abscissa represents local time.

reactions, but rather a plausibility check whether condensation and coagulation played a substantial role in the observed diurnal cycle of Aitken mode concentrations.

The submicrometer particle population was described by a sectional aerosol model. Experimental particle number size distributions served as the initial input of the model. Two processes were allowed to modify the particle number size distribution, condensation of sulfuric acid and coagulation. 


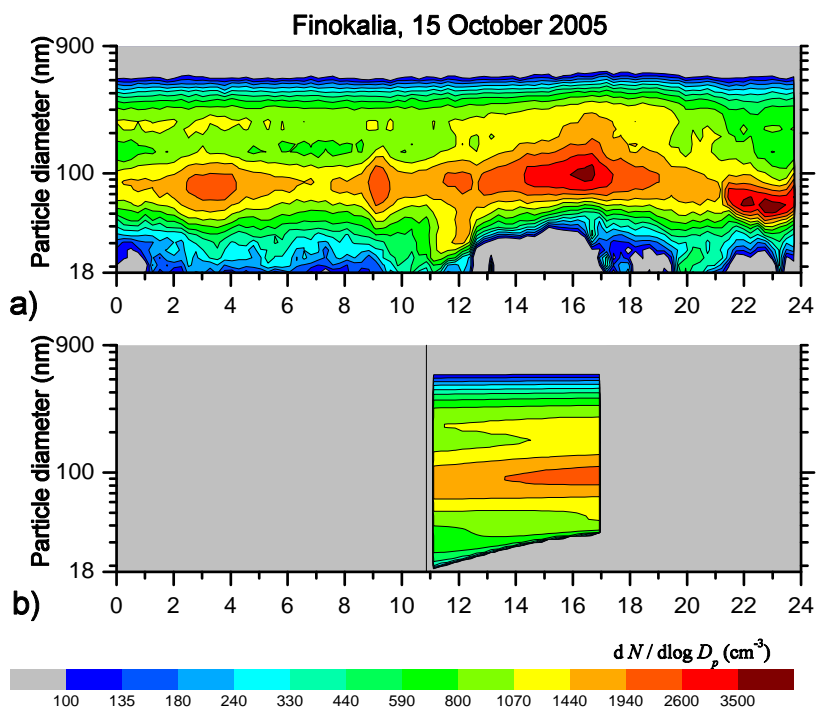

Fig. 10. Particle number size distributions at Finokalia on 15 October 2005: (a) Measurement illustrating a rather abrupt disappearance of Aitken mode particles during mid-day, (b) box model simulation starting at 11:00 LT and involving only condensation and particle coagulation. Abscissa represents local time.

Condensation of condensable species will cause a growth of individual particles and process the particle number size distribution. Since condensation in the transition regime causes a growth of all particles by a similar diameter increment, condensation was accounted for by moving the sections of the aerosol model. As sulphuric acid $\left(\mathrm{H}_{2} \mathrm{SO}_{4}\right)$ was assumed as the only condensable species, condensational growth was governed by the diffusion of sulphuric acid monomers. Mass transfer rates were calculated assuming spherical particles, a mass accommodation coefficient $\alpha$ of unity, and Dahneke's interpolation formula for vapor diffusion in the transition regime (Seinfeld and Pandis, 1998). Immediate neutralization with ammonia was assumed to take place, forming particulate ammonium sulphate.

$\mathrm{H}_{2} \mathrm{SO}_{4}$ concentrations were calculated from a simple chemical mass balance model considering production via the reaction of $\mathrm{OH}$ and $\mathrm{SO}_{2}$, and the loss onto pre-existing aerosol (i.e., the condensational sink term CS) by using a pseudo-steady state approximation (e.g., Weber et al., 1997):

$k \cdot\left[\mathrm{SO}_{2}\right][\mathrm{OH}]=\left[\mathrm{H}_{2} \mathrm{SO}_{4}\right] \cdot \mathrm{CS}$

with $k=8.5 \cdot 10^{13} \mathrm{~cm}^{3} \mathrm{~s}^{-1}$ (DeMore et al., 1997). The diurnal cycle of $\mathrm{OH}$ was assumed to closely follow that of solar radiation. A general mean diurnal cycle with a peak value of $2 \cdot 10^{7} \mathrm{~cm}^{-3}$ was assumed for this study, based on earlier work at Finokalia (Berresheim et al., 2003). As shown in previous studies for the Mediterranean atmosphere, the simplistic mass balance approach was able to reproduce $\mathrm{H}_{2} \mathrm{SO}_{4}$ concentrations with a measure of determination $R^{2}=0.86$ (Bardouki et al., 2003; Mihalopoulos et al., 1997).
The coagulation losses of particle number size concentration were calculated using the Dahneke kernel for particle diffusion in the transition regime (Seinfeld and Pandis, 1998). Since the size distribution change of lowconcentration polydisperse aerosol populations is predominantly located in the size range below $100 \mathrm{~nm}$, our aerosol model only accounted for coagulation losses of smaller particles onto bigger particles. In fact, no gain in particle diameter of larger particles was considered, thereby avoiding the need to numerically treat the complicated transition of larger particles from one to another size bin.

On any account, several limitations of the model need to be kept in mind during the discussion of the simulation results: The absence of condensable species beyond $\mathrm{H}_{2} \mathrm{SO}_{4}$ (this limitation is thought to be critical only for species with a diurnal cycle different from that of solar radiation), no new particle formation was considered during the mid-day observation period (i.e., only the existing size distribution is allowed to evolve with time), the requirement of a quasi Lagrangian observation, i.e., no significant air mass changes were accounted for during the simulation period.

\subsection{Comparison between model results and observations}

Two case studies were chosen to model the depletion of young Aitken particles. The aim was to explore impacts of variable precursor concentrations and condensational growth of the particle population and compare the results with observed number size distributions. Consecutive runs assuming different levels of $\mathrm{H}_{2} \mathrm{SO}_{4}$ were performed in order to estimate the total amount of vapors required to simulate the observed depletion of Young Aitken mode particles. In both cases best coherence was achieved using peak values for sulfuric acid of $1-2 \cdot 10^{7}$ molecules $\mathrm{cm}^{-3}$. The above mentioned values are representative for the site of Finokalia station (Bardouki et al., 2003). Dry particle density was assumed to be $1.6 \mathrm{~g} \mathrm{~cm}^{-3}$ based on chemical analysis results for the investigated period, while wet particle growth factor was assumed 1.15. Sensitivity tests showed no temperature dependence in the range $283 \mathrm{~K}$ to $313 \mathrm{~K}$, which is representative for the temperatures recorded during this study.

The first case study corresponds to the event of 7 October 2005 and is representative of the first pattern (gradual depletion). As shown in Fig. 9a the depletion of Young Aitken particles began around 08:00 LT and lasted for about $10 \mathrm{~h}$. The simulated condensation process (Fig. 9b) agrees well in both pattern and the depletion diameter cut off of $30 \mathrm{~nm}$. Within the entire run, the bimodal distribution and the convergence of the two modes to one, at the end of the run, are well simulated. The modelled and observed total particle number concentrations, corresponding to the value at the end of the run, coincide within $7 \%$, ensuring the stability of the air mass and the validity of the comparison made.

The second case of 15 October 2005 is characteristic of the second pattern described above (Fig. 10). In particular, 
an abrupt depletion was observed after 11:00 LT with a total duration of about $6 \mathrm{~h}$ (Fig. 10a). The observed depletion diameter cut off is $40 \mathrm{~nm}$ and is well captured by the model. The enhanced Aitken mode values after 14:00 LT are simulated in the model and the evolution of the distribution follows in general the nature of the measurement (Fig. 10b). The deviationbetween the modelled and observed total particle number concentrations at the final stage of the run is about $30 \%$, possibly indicating inflow of accumulation mode particles.

Although the approach followed is simplistic, we were able to reproduce the time scale and the intensity of the phenomenon of depletion of Aitken mode particles, as well as the evolution of the particle number size distribution. An important conclusion hereof is that the formation of particles $<50 \mathrm{~nm}$ seems to be absent despite the large amounts of solar radiation observed.

\section{Conclusions}

An intensive field study was conducted at the environmental research station Finokalia of the University of Crete, Greece, in order to better understand the variability and climatic relevance of atmospheric particles in the Eastern Mediterranean. The average total particle number concentration (Diameter $>18 \mathrm{~nm}$ ) was found to be $1800 \mathrm{~cm}^{-3}$ with values ranging between $360 \mathrm{~cm}^{-3}$ and $4560 \mathrm{~cm}^{-3}$. On average, half of the total particle concentration was assigned to accumulation mode (100-1000 nm), one third to the Aitken mode (50$100 \mathrm{~nm})$ and the rest to the Young Aitken particles (18$50 \mathrm{~nm})$. Coarse particles $(1-10 \mu \mathrm{m})$ were limited in number throughout the measuring period but they could significantly contribute to the total particle volume (up to $30 \%$ ) and mass. Four periods were selected corresponding to distinct synoptic air masses types. Periods $\mathrm{A}$ and $\mathrm{C}$ represented maritime air masses featuring low to moderate particle concentrations (900-2000 $\mathrm{cm}^{-3}$ ) while periods B and D represented air masses influenced by the European continent with elevated concentrations $\left(1800-2900 \mathrm{~cm}^{-3}\right)$. Depending on the air mass origin two structures of particle number size distributions were confirmed: bimodal in background marine conditions (periods $\mathrm{A}$ and $\mathrm{C}$ ), and unimodal in polluted continental air masses. Apparent particle density calculations were performed combining electromobility analysis and gravimetric techniques. Median densities for fine particles ranged between $1-1.7 \mathrm{~g} \mathrm{~cm}^{-3}$, while mass closure between the two different techniques was satisfactorily achieved.

During the entire campaign, only three occasions of secondary new particle formation (observational diameter range $18-50 \mathrm{~nm}$ ) were detected. The three events were short-lived observations, with a duration of less than two hours each, and featured particle formation rates $1.1-1.7 \mathrm{~cm}^{-3} \mathrm{~s}^{-1}$. It is worth to note that no large-area particle nucleation and growth events that are typical for the continental boundary layer (Kulmala et al., 2004; Heintzenberg et al., 2007) were observed. It is currently unclear why the production of new particles in the Eastern Mediterranean atmosphere is suppressed, given its high potential of photochemical precursor production.

On almost every second day, the diurnal cycle of the particle size distribution featured a systematic disappearance (depletion) of Young Aitken particles. Two types of depletion were observed, a gradual one with in general low depletion rates and one with higher depletion rates which was observed only during daytime and correlated with solar radiation. We compared these observations with simplistic box model simulations of the particle size distribution involving only condensation of $\mathrm{H}_{2} \mathrm{SO}_{4}$ and coagulation on larger particles. Despite the simplistic approach, the relative agreement of observations and simulations suggest that during the days of Aitken particle depletion, condensation and coagulation are the main factors shaping the evolving size distribution. The comparison adds up to the impression that nucleation of new particles is either insignificant over the Eastern Mediterranean, or that newly formed particles are rapidly scavenged before reaching the observational size limit of $18 \mathrm{~nm}$.

Acknowledgements. This work was supported by the Greek State Scholarships Foundation and by the Atmospheric Composition Change - The European Network of Excellence (ACCENT). The data evaluation for this paper were conducted within the European Integrated project on Aerosol Cloud Climate and Air Quality Interactions (EUCAARI), coordinated by M. Kulmala. The authors also acknowledge the NOAA Air Resources Laboratory (ARL) for the provision of the HYSPLIT transport and dispersion model (http://www.arl.noaa.gov/ready/hysplit4.html) used in this publication.

\section{Edited by: V.-M. Kerminen}

\section{References}

Bardouki, H., Berresheim, H., Vrekoussis, M., Sciare, J., K ouvarakis, G., Oikonomou, K., Schneider, J., and Mihalopoulos, N.: Gaseous (DMS, MSA, $\mathrm{SO}_{2}, \mathrm{H}_{2} \mathrm{SO}_{4}$ and DMSO) and particulate (sulfate and methanesulfonate) sulfur species over the northeastern coast of Crete, Atmos. Chem. Phys., 3, 1871-1886, 2003 ,

http://www.atmos-chem-phys.net/3/1871/2003/.

Berresheim, H., Plass-Dülmer, C., Elste, T., Mihalopoulos, N., and Rohrer, F.: $\mathrm{OH}$ in the coastal boundary layer of Crete during MINOS: Measurements and relationship with ozone photolysis, Atmos. Chem. Phys., 3, 639-649, 2003,

http://www.atmos-chem-phys.net/3/639/2003/.

Birmili, W., Stratmann, F., and Wiedensohler, A.: Design of a DMA-Based Size Spectrometer for a Large Particle Size Range and Stable Operation, J. Aerosol Sci., 30, 549-553, 1999.

Birmili, W., Berresheim, H., Plass-Dlmer, C., Elste, T., Gilge, S., Wiedensohler, A., and Uhrner, U.: The Hohenpeissenberg aerosol formation experiment (HAFEX): a long-term study including size-resolved aerosol, $\mathrm{H}_{2} \mathrm{SO}_{4}, \mathrm{OH}$, and monoterpenes measurements, Atmos. Chem. Phys., 3, 361-376, 2003, http://www.atmos-chem-phys.net/3/361/2003/. 
DeMore, W. B., Sander, S. P., Golden, D. M., Hampson, R. F., Kurylo, M. J., Howard, C. J., Ravishankara, A. R., Kolb, C. E., and Molina, M. J.: Chemical kinetics and photochemical data for use in stratospheric modeling, Evaluation number 12, JPL Publ., 97-4, 1997.

Draxler, R. R. and Hess, G. D.: An overview of the HYSPLIT 4 modelling system for trajectories, dispersion and deposition, Aust. Meteorol. Mag., 47, 295-308, 1998.

Gerasopoulos, E., Koulouri, E., Kalivitis, N., Kouvarakis, G., Saarikoski, S., Mäkelä, T., Hillamo, R., and Mihalopoulos, N.: Size-segregated mass distributions of aerosols over Eastern Mediterranean: seasonal variability and comparison with AERONET columnar size-distributions, Atmos. Chem. Phys., 7, 2551-2561, 2007,

http://www.atmos-chem-phys.net/7/2551/2007/.

Gerasopoulos, E., Kouvarakis, G., Vrekoussis, M., Kanakidou, M., and Mihalopoulos, N.: Ozone variability in the marine boundary layer of the Eastern Mediterranean based on 7-year observations, J. Geophys. Res., 110, D15309, doi:10.1029/2005JD005991, 2005.

Haywood, J. and Boucher, O.: Estimates of the Direct and Indirect Radiative Forcing due to Tropospheric Aerosols: A Review, Rev. Geophys., 38, 513-543, 2000.

HEI Health Review Committee and Scientific Staff: Understanding the health effects of components of the particulate matter mix: progress and next steps, HEI Perspectives, Cambridge, Mass: Health Effects Institute, 2002.

Heintzenberg, J., Wehner, B., Birmili, W.: "How to find bananas in the atmospheric aerosol": new approach for analyzing atmospheric nucleation and growth events, Tellus, B59(2), 273-282, 2007.

Kalivitis, N., Gerasopoulos, E., Vrekoussis, M., Kouvarakis, G., Kubilay, N., Hatzianastassiou, N., Vardavas, I., and Mihalopoulos, N.: Dust transport over the eastern Mediterranean derived from Total Ozone Mapping Spectrometer, Aerosol Robotic Network, and surface measurements, J. Geophys. Res., 112, D03202, doi:10.1029/2006JD007510, 2007.

Kulmala, M., Vehkamäki, H., Petäjä, Dal Maso, M., Lauri, A., Kerminen, V.-M., Birmili, W., and McMurry, P. H.: Formation and growth rates of ultrafine atmospheric particles: A review of observations, J. Aerosol Sci., 35, 143-176, 2004.

Lelieveld, J., Berresheim H., Borrmann, S., Crutzen, P. J., Dentener, F. J., Fischer, H., Feichter, J., Flatau, P. J., Heland, J., Holzinger, R., Korrmann, R., Lawrence, M. G., Levin, Z., Markowicz, K. M., Mihalopoulos, N., Minikin, A., Ramanathan, V., de Reus, M., Roelofs, G. J., Scheeren, H. A., Sciare, J., Schlager, H., Schultz, M., Siegmund, P., Steil, B., Stephanou, E. G., Stier, P., Traub, M., Warneke, C., Williams, J., and Ziereis, H.: Global air pollution crossroads over the Mediterranean, Science, 298, 794799, 2002.

Lide, D. R.: CRC Handbook of Chemistry and Physics, CRC Press Inc, USA, 1991.

Lohmann, U. and Feichter, J.: Global indirect aerosol effects: a review, Atmos. Chem. Phys., 5, 715-737, 2005, http://www.atmos-chem-phys.net/5/715/2005/.

Maenhaut, W., Hillamo, R., Makela, T., Jafferzo, J.-L., Bergin, M. H., and Davidson, C. I.: A new cascade impactor for aerosol sampling with subsequent PIXE analysis, Nucl. Inst. Meth. in Phys. Res., 109/110, 482-487, 1996.
Markowicz, K. M., Flatau, P. J., Ramana, M. V., Crutzen, P. J., and Ramanathan, V.: Absorbing Mediterranean aerosols lead to a large reduction in the solar radiation at the surface, Geophys. Res. Lett., 29(20), 1968, doi:10.1029/2002GL015767, 2002.

Mihalopoulos, N., Stephanou, E., Kanakidou, M., Pilitsidis, S., and Bousquet, P.: Troposheric aerosol ionic composition above the eastern Mediterranean area, Tellus, 49B, 314-326, 1997.

Penner, J. E., Chuang, C. C., and Grant, K.: Climate forcing by carbonaceous and sulfate aerosols, Clim. Dynam., 14(12), 839852, 1998.

Peters, T. M. and Leith, D.: Concentration measurement and counting efficiency of the aerodynamic particle sizer 3321, J. Aerosol Sci., 34, 627-634, 2003.

Petäjä, T., Kerminen, V.-M., Dal Maso, M., Junninen, H., Koponen, I. K., Hussein, T., Aalto, P. P., Andronopoulos, S., Robin, D., Hämeri, K., Bartzis, J. G., and Kulmala, M.: Sub-micron atmospheric aerosols in the surroundings of Marseille and Athens: physical characterization and new particle formation, Atmos. Chem. Phys., 7, 2705-2720, 2007,

http://www.atmos-chem-phys.net/7/2705/2007/.

Ravishankara, A. R.: Heterogeneous and Multiphase Chemistry in the Troposphere, Science, 276, 1058-1065, 1997.

Saarikoski, S., Mäkelä, T., Hillamo, R., Aalto, P. P., Kerminen, V.-M. and Kulmala, M. : Physico-chemical characterization and mass closure of size-segregated atmospheric aerosols in Hyytiälä, Finland, Boreal Environ. Res., 10, 385-400, 2005.

Sciare, J., Oikonomou, K., Cachier, H., Mihalopoulos, N., Andreae, M. O., Maenhaut, W., and Sarda-Estève, R.: Aerosol mass closure and reconstruction of the light scattering coefficient over the Eastern Mediterranean Sea during the MINOS campaign, Atmos. Chem. Phys., 5, 2253-2265, 2005, http://www.atmos-chem-phys.net/5/2253/2005/.

Seinfeld, J. H. and Pandis, S. P.: Atmospheric Chemistry and Physics, 2nd Edition, John Wiley, New York, 1998.

Solomon, S., Qin, D., Manning, M., Chen, Z., Marquis, M., Averyt, K. B., Tignor, M., and Miller, H. L.: Climate Change 2007: The Physical Science Basis, IPCC, contribution of Working Group I to the Fourth Assessment Report of the Intergovernmental Panel on Climate Change (IPCC), Cambridge Univ. Press, Cambridge, United Kingdom, 2007.

Turpin, B. J. and Lim, H.-J.: Species Contributions to $\mathrm{PM}_{2.5}$ Mass Concentrations: Revisiting Common Assumptions for Estimating Organic Mass, Aerosol Sci. Technol., 35, 602-610, 2001.

Vrekoussis, M., Liakakou, E., Kocak, M., Kubilay, N., Oikonomou, K., Sciare, J., Mihalopoulos, N.: Seasonal variability of optical properties of aerosols in the Eastern Mediterranean, Atmos. Environ., 39, 7083-7094, 2005.

Weber, R. J., Marti, J. J., McMurry, P. H., Eisele, F. L., Tanner, D. J., and Jefferson, A.: Measurement of new particle formation and ultrafine particle growth rates at a clean continental site, J. Geophys. Res. 102, 4375-4385, 1997.

Winklmayr, W., Reischl, G. P., Linde, A. O., and Berner, A.: A New Electromobility Spectrometer For the Measurement of Aerosol Size Distributions in the Size Range from 1 to $1000 \mathrm{~nm}$, J. Aerosol Sci., 22, 289-296, 1991.

WHO: Health Effects of Air Pollution Results from the WHO Project Systematic Review of Health Aspects of Air Pollution in Europe, Tech. rep., World Health Organisation, 2004. 